\title{
Feasibility of near-infrared spectroscopic observation for traditional fermented soybean production
}

\author{
Jae Hwan Jeon, Seon Mi Lee, Rae Kwang Cho* \\ School of Applied Biosciences, Kyungpook National University, Daegu 41566, Korea \\ 전통 메주 제조과정에 있어서 근적외 모니터링 가능성 조사 \\ 전재환 · 이선미 · 조래광*
경북대학교 응용생명과학부
}

\begin{abstract}
In this study, near infrared (NIR) spectroscopy known as a non-destructive analysis technique was applied to investigate peptide cleavage and consequent release of amino acids in soybean lumps as affected by its moisture content and incubation time during fermentation at 25 for 3 weeks. The NIR spectra of the soybean lump semi-dried and soaked in saline water showed that absorption intensity around $1,400 \mathrm{~nm}$ originating from hydrogen bonds of water decreased and absorption band shifted to $1,430 \mathrm{~nm}$ as moisture content decreased during incubation at 25 for 3 weeks. In addition, absorption around $2,050 \mathrm{~nm}$ which was assigned to amino groups increased as incubation time increased. NIR spectra data from 1,000 to $2,250 \mathrm{~nm}$ showed higher accuracy in the discriminant analysis between outside and inside parts of fermented soybean lumps than visible spectra result. NIR spectroscopy for the amino acid and moisture contents in traditional fermented soybean lumps showed relatively good accuracy with the multiple correlation coefficient $\left(R^{2}\right)$ of 0.91 and 0.81 , respectively, and root mean square error of cross validation (RMSECv) of 0.23 and $0.83 \%$, respectively, in partial least square regression (PLSR). These results indicate that NIR spectral observations could be applicable to control the fermentation process for preparation of soybean products.
\end{abstract}

Key words : Near infrared spectroscopy, moisture content, amino acid, soybean fermentation, melanoidin

\section{서 론}

식품의 품질분석을 위해 측정하여야 할 다양한 항목을 기존의 물리화학적 분석방법으로 분석하기에는 인력과 시 간 및 고가의 장비들이 필요하며, 소모성 시약 및 분석 폐액 처리를 위해 많은 경제적 부담이 따르므로 이러한 문제점을 개선할 목적으로 신속 간편한 비파괴분석기술인 근적외 분석법이 개발되었다(1).

장류의 제조공정은 원료처리, 제국, 발효숙성, 제성, 배합 살균, 냉각, 포장으로 구성되어 있는데, 특히 제국과 발효

*Corresponding author. E-mail : rkcho@knu.ac.kr

Phone : 82-53-950-5719, Fax : 82-53-953-7233

Received 3 January 2017; Revised 24 January 2017; Accepted 31 January 2017.

Copyright (c) The Korean Society of Food Preservation. All rights reserved.
숙성과정중의 품질 및 공정관리는 생산수율과 맛, 향기, 색상에 중요한 영향을 미치기 때문에 발효물의 화학적, 생 화학적인 성분변화를 필요 때마다 즉시 측정 할 수 있는 분석법을 도입하여 공정관리를 해야만 좋은 제품을 생산할 수 있다(2).

전통 양조 가공품 중 일본의 시판 된장을 대상으로 쌀 $K o j i \ddot{i}$ 에 의한 단백질의 가수 분해 정도를 파악하기 위한 척도 로서 가용성 질소와 아미노산 질소를 측정하고 있으며 된장 의 숙성 정도를 알 기 위해 젖산과 알코올 함량을 파괴 측정하고 있는데 숙련된 전문 분석자들이 된장시료 20점의 수분, 소금, 전당, 전질소, 지질, 회분, 직접환원당, 가용성질 소, formol 질소, 젖산 및 알코올 함량을 측정하는데 만 2 일 이 소요되어, 출하 공정에 필요한 측정 결과를 얻는데 애로 가 많아서 이를 해결하고자 근적외 분석법이 도입되었다 (3).

이들이 물기가 많은 된장시료의 근적외 스펙트럼을 측정 
할 때 직경 $8.3 \mathrm{~cm}$ 이고, 깊이 $0.9 \mathrm{~cm}$ 로 가운데가 패인 시료 컵에 담은 후 표면을 스푼으로 고른채 측정하였는데 이와 유사한 배경으로 물기가 대부분인 간장의 전질소, 가 용성 고형물, 식염, 알콜, 산도, $\mathrm{pH}$, 보메도, 직접환원당 및 글루타민산 함량을 근적외 분석법으로 측정하기 위해 간장 시료를 자동시료채취기로 주액한 뒤 품온이 일정하게 유지 되도록 순환온수펌프를 채택한 연속 측정 시스템으로 양호 한 측정 결과를 보고하였다(4).

국내에서는 시판양조간장과 산분해간장을 대상으로 판 별가능성을 근적외 분석법으로 조사한 결과 $100 \%$ 구별된 다는 보고가 있다(2).

메주의 발효 숙성 중 방부 목적으로 오랜 기간 동안 사용 되어온 소금이 최근 건강에 미치는 영향이 지적되기 시작하 면서 전통 장류의 판매량이 줄어들고 한식업계가 어려움을 겪고 있다. 나트륨 이온이 장류의 숙성 중에 생성되는 멜라 노이딘 구조 속에 들어가 소화과정을 거쳐도 체외로 배설될 만큼 안정한 결합을 하고 있을 것이라는 기초연구가 보고되 어 있으나, 구체적으로 입증할만한 연구근거가 부족한 실 정이다(5). 간장의 저염화를 위해서 제조비용이 들더라도 투석이나 막처리 기술을 구사할 수 있지만(6) 된장은 페이 스트 상태이어서 압착하거나 여과 할 수 없어 적용할 수 있는 연구개발에 애로를 겪고 있으며, 이를 해결하기 위하 여 여러모로 모색하고 있으나 근본적인 대책이 미흡한 실정 이다(7-8)

전통장류 제조과정 중 아플라톡신이 생겨날 우려가 남아 있어 이를 조사한 연구 등(9) 전통장류의 소비를 촉진하기 위해서는 장류제조과정을 보다 과학적으로 해석하여 객관 적인 공정을 수립할 수 있는 연구가 필요한데 본 연구에서 는 생메주의 건조과정과 발효메주의 단백질 분해 및 아미노 산 생성관계를 근적외 분광으로 쉽게 파악할 수 있는지 그 가능성을 조사하였다.

\section{재료 및 방법}

\section{생메주}

2015년 11월 초순에 경상북도 청도군 금천면 전통메주 전문업체에서 국산콩을 삶아 으깬 뒤 $23 \times 20 \times 12 \mathrm{~cm}$ 크기로 만든 생메주를 구입하여 냉동보존하며 사용하였다.

\section{전통 발효메주}

상기 생메주를 볏짚으로 묶어 통풍이 잘되는 한옥 처마 아래에서 1 개월간 말리면서 접균 시킨 뒤 $20^{\circ} \mathrm{C}$ 토방에 벽돌 모양으로 쌓아서 2 개월간 보존하여 만든 발효메주를 실험 에 사용하였다.

\section{중간수분 발효메주}

상기 생메주를 $3 \times 4 \times 3 \mathrm{~cm}$ 크기로 잘라서 수분함량이
$30 \%$ 되게 말린 뒤 그 표면에 전통메주가루를 고루 묻혀서 보습을 위해 종이타올(Wypall X70, Yuhan-Kimberly, Seoul, Korea)로 싸서 $25^{\circ} \mathrm{C}$ 항온기에 넣고, 3 주간 유지하면서 시료 를 채취하였다.

\section{부위별 시료의 조제}

전통 발효메주의 표면을 $5 \mathrm{~mm}$ 정도 벗겨내고 그 아래층 $20 \mathrm{~mm}$ 까지를 겉 부분, 나머지 속 부분으로 잘게 자른 뒤, 분쇄기(HMF-502, Hanil, Seoul, Korea)로 가루로 만들어 실험에 사용하였다.

\section{소금물 추출}

상기 분말 시료 $3 \mathrm{~g}$ 과 소금물 $20 \mathrm{~mL}$ 를 팔콘 튜브에 넣고 $20^{\circ} \mathrm{C}$ 에서 24시간 진탕 추출(BF-30SI, Biofree, Korea)한 뒤, $4,000 \mathrm{rpm}$ 에서 20 분간 원심분리(Low speed centrifuge 416 , Labo gene, Seoul, Korea)한 상징액을 여과하여 분석에 사용 하였다.

\section{수분함량측정}

중간수분 메주 시료의 수분함량은 시료 크기를 $2 \times 2 \times 1$ $\mathrm{cm}$ 가 되게 절단하여 바닥에 구멍이 뚫린 알루미늄 접시 $(\varnothing 80 \mathrm{~mm})$ 에 얹은 뒤 $50^{\circ} \mathrm{C}$ 에서 48 시간 동안 온풍 건조 (LD-918BH, L'equip, Hwaseong, Korea)시켜 계산하였고, 발효메주의 수분 함량은 스테인레스 용기 $(\varnothing 75 \mathrm{~mm})$ 에 담아 온풍건조(약 $70^{\circ} \mathrm{C}, 48$ 시간)시켜 계산하였다(10).

\section{아미노산 함량 측정}

메주의 소금물 추출액 $0.1 \mathrm{~mL}$ 에 ninhydrin용액(Tokyo Chemical Industry Co., Tokyo, Japan) $1 \mathrm{~mL}$ 와 증류수 $4 \mathrm{~mL}$ 넣고 $90^{\circ} \mathrm{C}$ 에서 20 분간 가열하여 정색반응 시킨 뒤 $570 \mathrm{~nm}$ 에서 흡광도를 측정하여, Glutamic acid(Samchun Pure Chemical, Gyeonggi-do, Korea)로 작성한 검량식 $\mathrm{y}=(\mathrm{x}+0.1427)$ $/ 0.6624, \mathrm{R}^{2}=0.99$ 에 대입하여 아미노산 함량을 산출하였다 (11).

\section{갈색도 측정}

메주추출액의 갈색도는 UV-Visible spectrophotometer (UV-1800, Shimadzu, Kyoto, Japan)로 $420 \mathrm{~nm}$ 에서 측정한 흡광도로 나타내었다(12).

\section{가시-근적외 스펙트럼 측정}

분말상태로 조제한 메주시료를 석영유리창이 부착되어 있는 밀폐시료용기(closed cup)에 약 $5 \mathrm{~g}$ 을 넣고 spatula로 표면을 고른 뒤 스펀지가 부착된 뚜껑으로 압박하여 잠근 뒤 CARY 5G(Varian, California, USA)시료 창에 밀착시켜 $400 \mathrm{~nm}-2,500 \mathrm{~nm}$ 까지 확산 반사모드로 가시 및 근적외 스펙트럼을 측정하였다(13). 


\section{스펙트럼의 해석 및 검량식 작성}

가시 및 근적외 스펙트럼의 해석은 $\mathrm{Camo}$ 사의 다변량 통계 소프트웨어 Unscrambler(v10.3, CAMO, Oslo, Norway) 를 이용하였다. 화학분석 데이터와 근적외 스펙트럼 데이 터 간에 오차를 최소화시키기 위하여 전처리로서 2차 미분, $\mathrm{SNV}$ (standard normal variate), smoothing처리를 적용하였 다. 검량식 작성에는 부분최소자승회귀분석(partial least square regression, PLSR)방법을 사용하였으며, 검량식의 정 확도 평가는 결정계수( $\mathrm{R}^{2}$, multiple correlation coefficient), 주성분(principal component, $\mathrm{PC}$ ), 및 검량식을 통하여 나온 검증오차인 $\mathrm{RMSECv}$ (root mean square error of cross validation)로 확인하였다(14).

\section{판별분석}

발효 메주의 겉 부분과 속 부분 시료 각각의 가시, 근적외 스펙트럼 자료의 판별분석에는 1,000-2,250 nm의 스펙트럼 자료를 이용하여 전처리로서 multiplicative scatter correction (MSC) 처리 후 1차미분한 자료를 Fisher's liner discriminant orthogonal decomposition(FDOD)방법으로 분석하였다(15).

\section{결과 및 고찰}

\section{중간수분상태로 건조한 생메주의 항온 보존 중 근적외 스 펙트럼 변화양상 조사}

수분 $60 \%$ 인 생메주를 약 $30 \%$ 까지 건조시킨 뒤 $25^{\circ} \mathrm{C}$ 항온 기에 넣고 3주간 보존하는 동안에 균의 번식정도가 점차 증가 되는 것을 관찰 할 수 있었다. 이들 시료의 근적외 스펙트럼을 측정하여 Fig. 1 에 나타내었는데 수분의 O-H에 기인되는 $1,000 \mathrm{~nm}, 1,400 \mathrm{~nm}$ 및 $1,900 \mathrm{~nm}$ 부근에서 흡수 피크가 관찰되 었으며, 대두 단백질의 -CONH와 아미노산의 $\mathrm{N}-\mathrm{H}$ 에 기인되 는 $2,170 \mathrm{~nm}$ 와 $2,060 \mathrm{~nm}$ 부근에서 흡수 피크가 관찰되며,

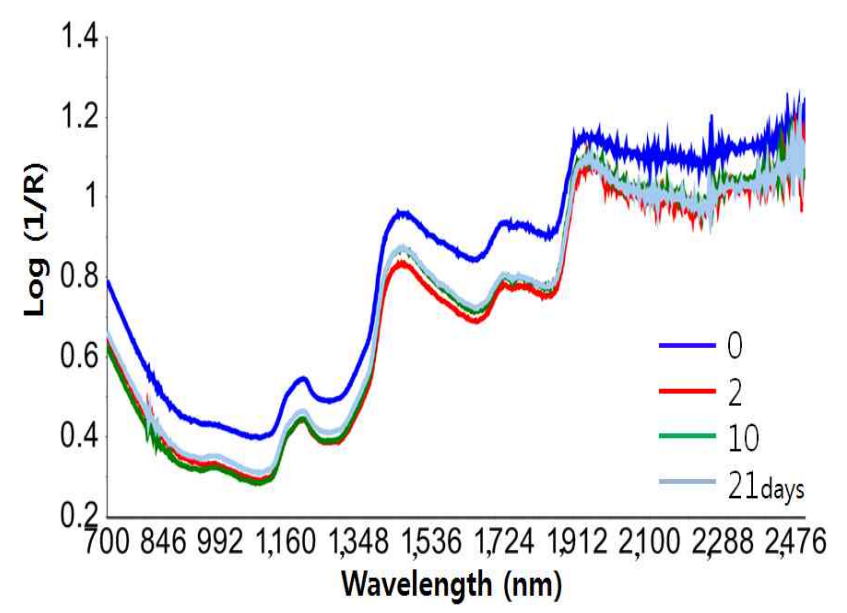

Fig. 1 NIR spectra of the model soybean lump after incubation at $25^{\circ} \mathrm{C}$ for 21 days.
대두지질의 $\mathrm{C}-\mathrm{H}$ 에 기인되는 $1,700 \mathrm{~nm}$ 부근에서 흡수피크가 관찰되었지만, $2,300 \mathrm{~nm}$ 에서는 뚜렷이 관찰할 수 없었다. 전반적으로 $2,000 \mathrm{~nm}$ 이상에서 노이즈가 심하게 나타나있 음을 볼 수 있었는데, 이는 메주분말시료의 표면에 수분이 번져나와 반사되었기 때문인 것으로 추정되며(16), 이들 시 료의 원(raw)스펙트럼 자료를 smoothing 및 2차 미분 처리함 으로서 Fig. 2와 Fig. 3과 같이 노이즈가 소거되어져 관찰이 훨씬 쉬워졌다(17).

항온기에서 메주가 발효되는 기간이 경과됨에 따라 수분 함량이 낮아지면서 물의 O-H에서 기인된 $980 \mathrm{~nm}$ 에서의 흡광도는 줄었으며, $1,416 \mathrm{~nm}$ 에서 $1,430 \mathrm{~nm}$ 쪽으로 시프트 되며 감소되는 것을 볼 수 있었다. 이는 발효 중 메주의 수소결합 상태가 느슨한 물이 먼저 증발되고 점차 수소 결합이 강한 물만 남게 되는 현상 때문에 시프트된 것으로 양념채소의 건조에 관한 연구에서도 물에 기인되는 흡수패 턴이 유사하게 보고된 바 있다(10). 2,056 nm에서는 3주에 이르는 동안 점차 흡수가 아래로 돌출됨을 볼 수 있는데, 이는 $2,170 \mathrm{~nm}$ 에서 흡수를 나타내는 대두단백질의 펩타이 드가 가수분해 되면서 그 결과 아미노기가 증가된 것으로 식품 단백질의 2 차 구조해석에 관한 연구와 폴리펩타이드 를 해석한 연구에서도 이들 파장영역에서의 흡수패턴이 소개된 바 있다(18-19).

\section{전통건조메주의 부위별 분석결과}

$20^{\circ} \mathrm{C}$ 조건에서 2 개월간 충분히 띄운 메주의 겉 부분은 속 부분에 비해 건조가 많이 이뤄져 있음을 Table 1 에서 볼 수 있는데, 수분이 상대적으로 2-3\% 높게 유지된 메주의 속 부분이 겉 부분에 비해 아미노산의 생성정도가 약 2 배정 도 높은 것을 알 수 있었다. 생메주의 사이즈가 발효메주의 품질과 연관하여 두께가 $12 \mathrm{~cm}$ 인 것 보다 얇은 $7 \mathrm{~cm}$ 인 것이 전반적으로 품질이 좋았다는 보고(20)가 있는데 이러 한 생메주의 건조 과정 중 접합된 자연계 미생물이 발효 중 단백질 분해 효소를 분비하기에 필요한 수분함량을 적절 히 공급하기 위한 조건을 설정하기 위한 연구에 도움이 될 것으로 사료된다.

전통메주의 속 부분이 겉 부분에 비해 갈색도가 1.2 배 정도 높음을 볼 수 있었는데, 전통된장의 짙고, 탁한 갈색이 밀과 쌀 $K o j i$ 를 쓰는 일본식 양조된장의 밝은 황색에 비해서 소비자가 싫어한다는 보고가 있으며(21-22), 된장의 색깔 개선에 대한 연구가 보고되어있다(23).

대두단백질이 메주 제조기간 중 가수분해되어 생성되는 글루타민산, 라이신 같은 아미노산과(24) 대두 유래의 환원 당이 아미노 카르보닐 반응하여 생겨난 3-deoxyglucoson (3-DG)같은 카르보닐 물질이 추가로 반응하여 갈색물질인 멜라노이딘을 생성하기도 하지만 한편으로는 디카르보닐 화합물인 3-DG가 미쳐 잘라지지 않은 대두 단백질과 부분 절단된 펩타이드와 결합하면 펩타이드 또는 단백질 자체가 

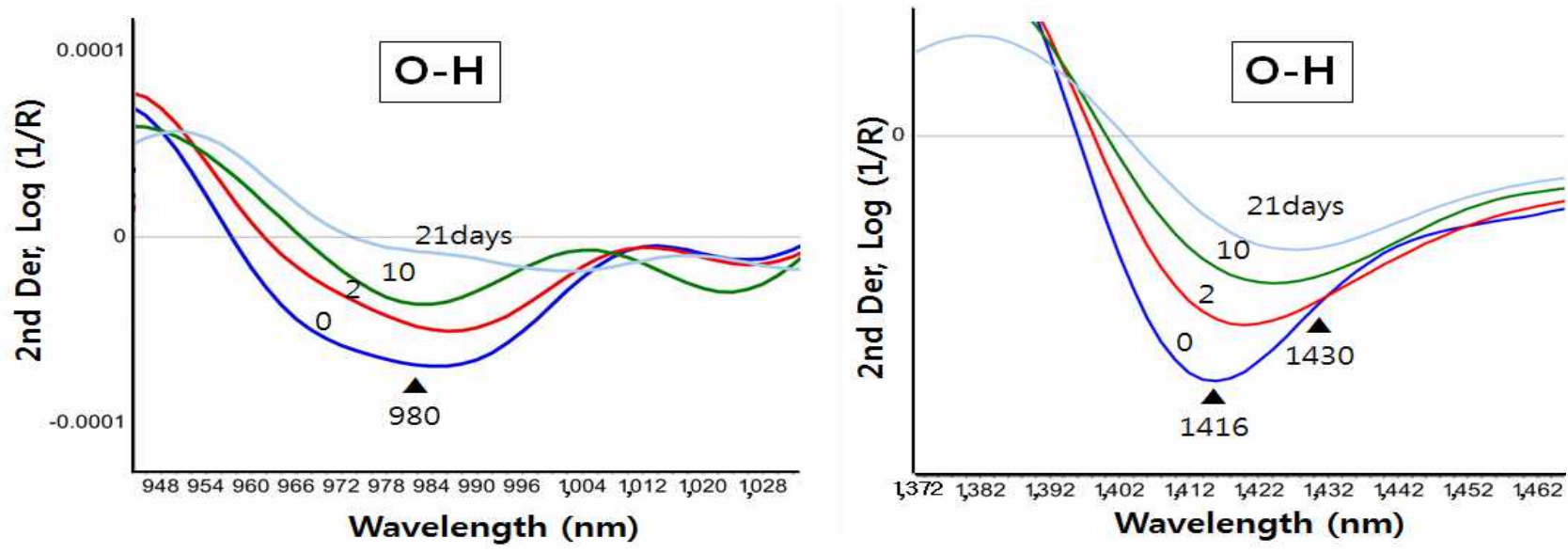

Fig. 2. The second derivative NIR spectra of the model soybean lump after incubation at $25^{\circ} \mathrm{C}$ for 21 days.
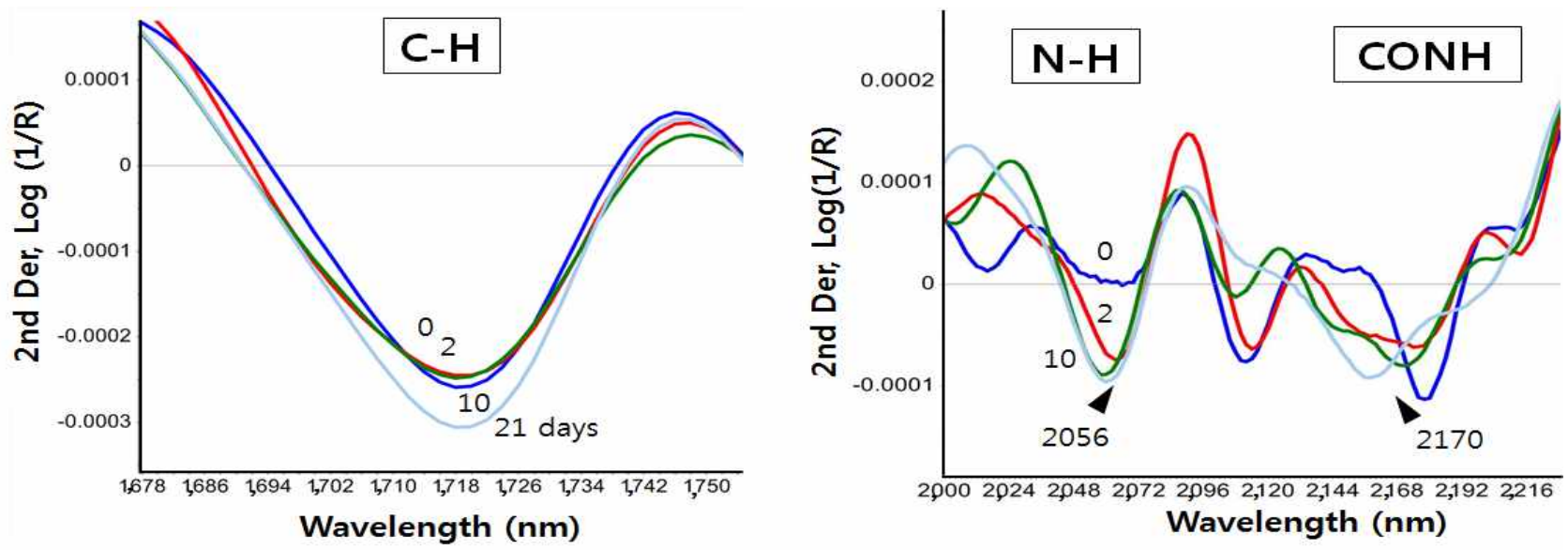

Fig. 3. The second derivative NIR spectra of the model soybean lump after incubation at $25^{\circ} \mathrm{C}$ for 21 days.

Table 1. Comparison of moisture content, brown color and amino acid content of the traditional fermented soybean lumps

\begin{tabular}{ccccccccc}
\hline \multirow{2}{*}{ Position } & \multirow{2}{*}{ Sample } & \multicolumn{2}{c}{ Moisture (\%) } & \multicolumn{2}{c}{ Amino acid (\%) } & \multicolumn{2}{c}{ Brown color (OD 420 nm) } \\
\cline { 3 - 8 } & & Range & Mean & Range & Mean & Range & Mean \\
\hline Inside & 18 & $6.01-9.98$ & 7.87 & $1.10-3.15$ & 2.02 & $0.22-2.56$ & 1.92 \\
Outside & 20 & $4.66-8.24$ & 6.21 & $0.88-1.98$ & 1.18 & $1.00-2.39$ & 1.65 \\
\hline
\end{tabular}

갈변되기도 하며, 이들 펩타이드간 크로스 링킹에 의해 중 합이 과도하게 일어나면 단백질의 불용화를 초래할 수 있다 는 기초적인 연구 결과가 있어 대두 단백질을 주원료로 사용하는 전통된장의 갈변을 개선시킬 수 있는 방법을 개발 하는데 참고가 될 것으로 사료된다(25-27).

\section{전통메주의 겉 부분과 속 부분의 판별 가능성 조사}

일반적으로 메주의 제조과정 중 온도와 습도가 중요하게 관여하는데 잔여 수분이 증발되지 않고 지켜질 수 있는 조건 일 때 발효가 잘 되어 목적한바 대로 잘 발효되었는지 눈으 로 보고 평가할 수밖에 없다. 본 연구에서 메주의 겉 부분과
속 부분 시료의 가시 스펙트럼 데이터를 사용하여 판별 분석 을 시도한 결과, Fig. 4와 같이 일부 오판되는 판별 결과를 보였다. 식용유생산에서 부산물로 나오는 탈지대두를 간장 원료로 사용하는 비율이 증가하게 되었는데, 전지 대두로 만든 간장의 풍미가 훨씬 부드러우며 맛이 좋다는 소비자 반응에 따라 고가임에도 불구하고 전지대두 간장의 판매량 이 $10 \%$ 나 증가하게 되어 전지대두와 탈지대두로 만든 간장 을 식별하기 위해 중적외 스펙트럼 영역 데이터 보다 근적 외 영역에서 훨씬 판별 정확도가 높았으며, 이때 Genetic 알고리즘을 채택함으로서 완벽히 판별할 수 있었다는 Kikkoman 연구팀의 보고가 있는데(28), 이 결과와 유사하 


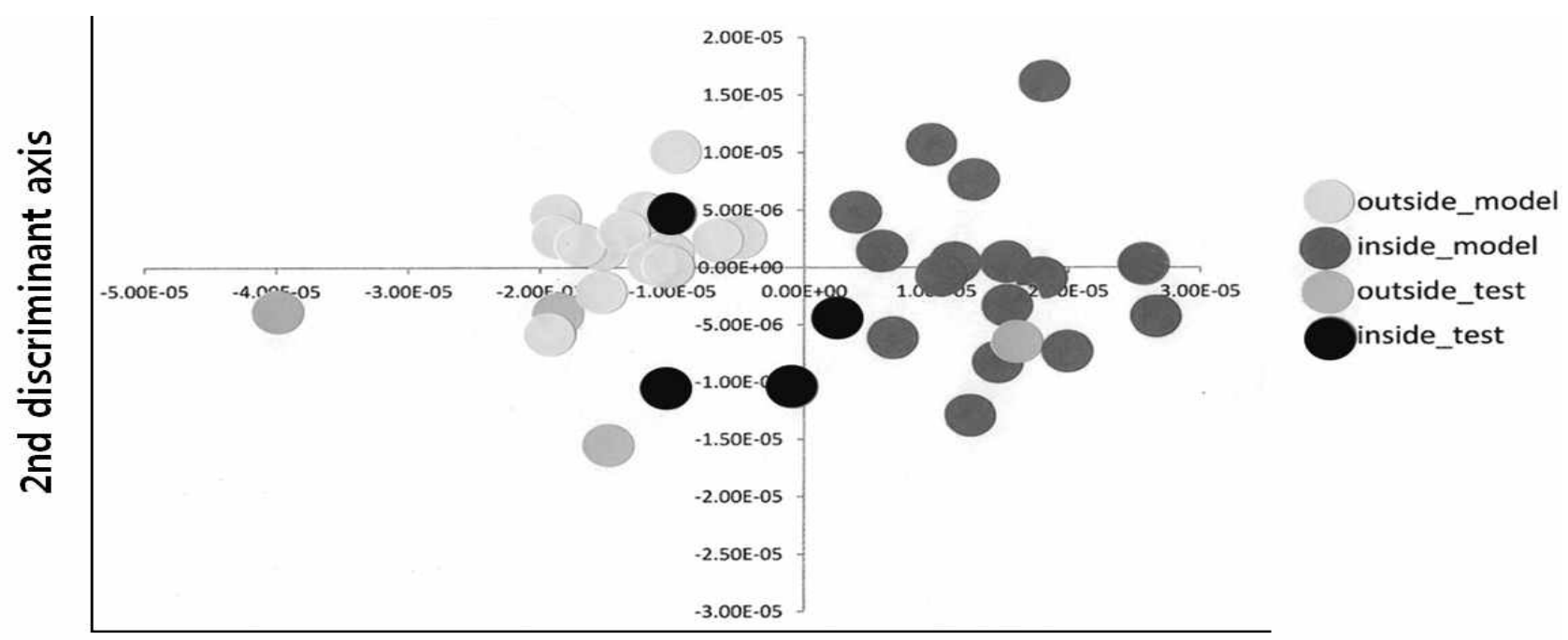

1st discriminant axis

Fig. 4. Discriminant analysis between outside part and inside parts of the traditional fermented soybean lumps using visible spectral data.

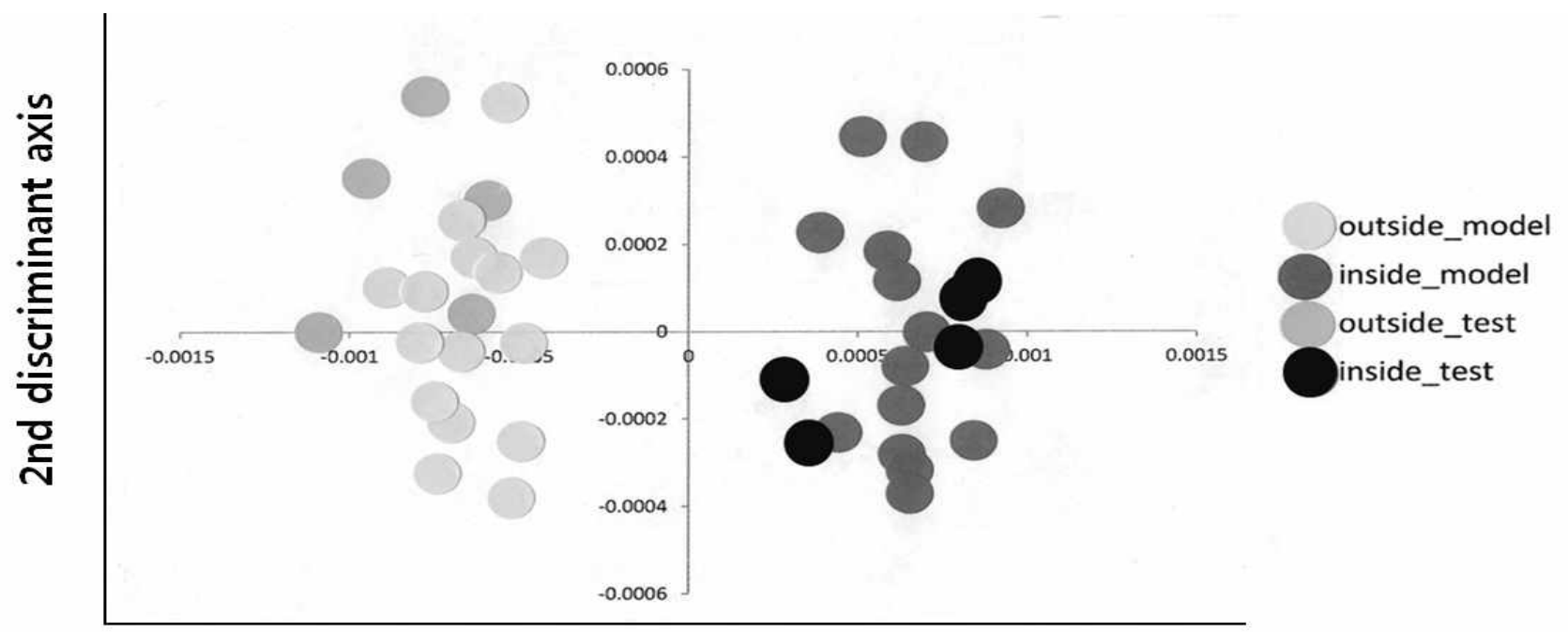

\section{1st discriminant axis}

Fig. 5. Discriminant analysis between outside part and inside parts of the traditional fermented soybean lumps using NIR spectral data.

게 Fig. 5에서는 분석자의 시각적 판단과 비슷한 가시광선 영역 데이터 보다 발효메주의 성분 정보가 풍부하게 들어있 는 근적외 영역 데이터에서 판별이 더 잘 이루어졌다고 생각된다(14)

전통메주에서 추출될 아미노산 함량과 수분의 비파괴 측 정가능성 조사

전통메주의 겉부분 시료와, 속부분 시료 38 점을 소금물 로 추출한 용액 중의 아미노산 함량을 ninhydrin 정색법으로 분석한 자료와, 이들 메주가루의 근적외 스펙트럼 자료 간 에 PLSR 분석한 결과를 Table 2와 Fig. 6에 나타내었다. 주성분 $(\mathrm{PC}) 6$ 에서 중상관계수 $\left(\mathrm{R}^{2}\right)$ 가 0.91 이고, 측정오차
(RMSECv) $0.23 \%$ 으로 가장 좋음을 알 수 있었다(Table 2). 성분치 폭에 비해 측정오차가 약 $1 / 10$ 이어서 메주에서 추 출될 아미노산 함량을 비파괴 예측 할 수 있는 가능성이 인정되었다. 장차 전통 장류의 제조에 대한 공정 개선이나 객관적인 계수화 작업이 가능할 것으로 기대된다. 중국에 서 간장중의 아미노산 질소를 기준으로 $0.4 \%$ 이상이면 고 급간장으로 인정 하고 있는데, 아미노산 질소를 분석할 때 인체에 유해한 포르말린을 쓰고 있는 현행 분석방법을 탈피 하기 위해 근적외 분석법을 활용함에 있어 Genetic 알고리 즘을 보강시킬 수 있는 개선된 소프트웨어를 도입함으로서 측정 정확도를 현저히 높일 수 있었다는 연구(29)에서와 같이 전통메주산업에서도 비파괴 측정 정확도를 높일 수 
있는 키모메트릭스 기법을 도입할 계획이다. 수분의 경우 도 Fig. 6과 같이 $\mathrm{PC} 5$ 에서, $\mathrm{R}^{2}$ 가 0.81이고, $\mathrm{RMSECv}$ 가 $0.83 \%$ 로 비파괴 측정이 가능할 것으로 판단되었다.

Table 2. Result of PLSR between NIR predicted Ninhydrin reacted amino acid content and moisture content of the traditional fermented soybean lumps

\begin{tabular}{ccccc}
\hline Component & Treatment & $\mathrm{PC}^{1)}$ & $\mathrm{R}^{2)}$ & $\mathrm{RMSECV}^{3)}(\%)$ \\
\hline Amino acid & None & 6 & 0.91 & 0.23 \\
Moisture & 2nd derivation & 5 & 0.81 & 0.83 \\
\hline
\end{tabular}

Number of samples : 38 .

${ }^{1)} \mathrm{PC}$, principal component.

${ }^{2)} R^{2}$, multiple correlation coefficient.

${ }^{3)} \mathrm{RMSECv}$, root mean square error of cross validation.

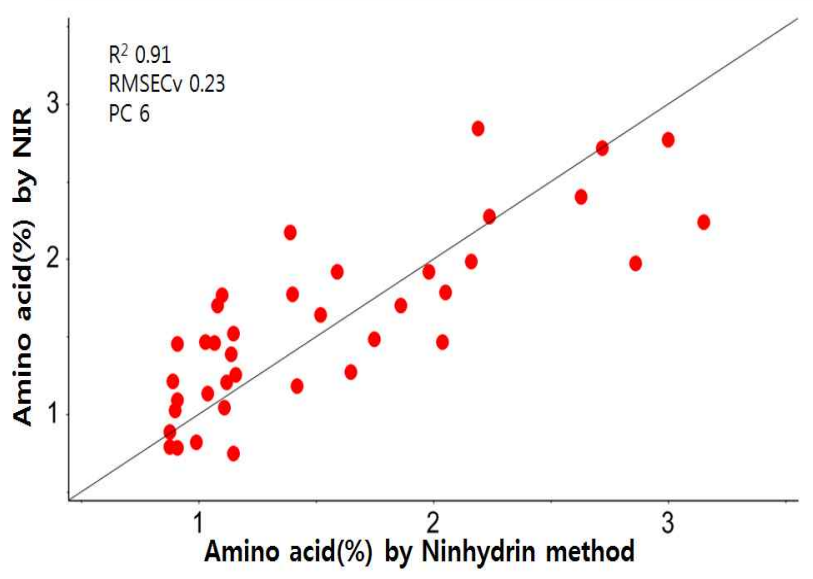

Fig. 6. Relationship between NIR predicted amino acid content and Ninhydrin reacted amino acid content of the traditional fermented soybean lump.

\section{전통장류의 비파괴적 품질연구에 대한 고찰}

전통 장류의 소비를 촉진하기 위해 제조 공정을 객관적 으로 수립하기 위해 본 논문에서는 생메주의 건조과정과 발효메주의 단백질 분해에 따른 아미노산의 생성관계를 근적외 분광법으로 해석하여 적용가능성이 있음을 알 수 있었는데, 이와 관련있는 연구로서 일본의 가정식 된장이 발효되는 동안 일어나는 화학적인 변화를 알기위해 근적외 스펙트럼을 측정하여 주성분 분석한 결과(30), 담금계절 및 숙성기간이 경과됨에 따라 확연한 경향 차이가 관찰된다 고 보고하였는데 구체적인 화학적 성분분석을 실시하지는 않았지만 단백질의 분자 사이즈에 변화가 예상된다고 추정 하고 있어, 그러한 연구의 변화해석에 본 연구결과가 도움 을 줄 수 있을 것으로 생각된다. 한편, 간장과 된장의 색깔, 냄새 및 맛에 관한 관능적 척도를 가시 및 근적외 스펙트럼 데이터와 PLSR하여 높은 상관이 얻어졌다는 보고(31)도 있어, 사람의 오관 중 특히 혀를 써서 평가하던 된장의 품질 평가법은 짠맛으로 인해 장시간 반복하여 검사하기 곤란했
었는데 이러한 취약점이 개선될 수 있을 것으로 전망된다.

간장이나 된장같은 고염 발효식품을 장기간 숙성시키는 동안 소금맛이 쏘지않고 순화되는 것은 멜라노이딘과 관련 이 있을 것으로 많은 식품학자들이 추정하고 있으나, 결정 적으로 뚜렷한 증거를 제시하지 못하고 있는데 Glucoselysin으로 멜라노이딘을 조제하여 측정한 가시 및 근적외 스펙트럼으로 멜라노이딘 생성에 대한 Kinetic 해석을 시도 한 기초적인 연구도 이루어지고 있다(32). 최근 한국과 일본 등에서 짠맛이 조금 덜한 감염 간장이나 된장이 상품으로서 많이 소개되고 있으나 아직 소금의 과잉 섭취에 대한 근본 적인 해결방안이 학술적으로 정립되지 못하였다(33). 상대 적으로 입맛이 떨어진 노년층이 행정부처의 가이드라인에 따라 습관적으로 먹어왔던 짠맛을 제대로 느끼지 못하게 조리된 음식물을 섭취해야 되기 때문에 식사를 통한 만족감 이 다소 저하되는 문제점이 지적되고 있으나 이를 개선하기 위한 적합한 공익적 연구시도가 부족한 상황이다. 이와 관 련하여 본 연구진이 별도로 수행한 실험에서 숙성기간이 7 년까지 경과된 간장시료에서 점도가 약 2 배 증가되고 짠 맛이 순하게 느껴지는 현상이 보였지만 숙성 간장 중의 멜라노이딘 구조에 소금이 결합되어 짠맛이 일부 완화되는 지를 밝히기 위해서는 추가연구가 수행될 필요가 있다.

\section{요 약}

본 연구에서는 전통 재래식 콩된장의 제조공정을 과학적 으로 해석하기 위한 연구의 일환으로 생메주의 건조 및 발효과정에 있어서 수분함량과 단백질 분해에 의한 아미노 산 생성과정을 근적외 분광법으로 쉽게 판단 할 수 있는지 그 가능성을 조사하였다. 생메주를 일정한 크기 $(3 \times 4 \times 3 \mathrm{~cm})$ 로 잘라서 수분이 $30 \%$ 가 되도록 $25^{\circ} \mathrm{C}$ 항온기에 3 주간 발효 시킨 모델계 발효메주를 만들어 가시광-근적외 스펙트럼을 측정하여 해석하였다. 발효가 진행됨에 따라 수분이 감소 되면서 수분과 관련이 있는 $1,430 \mathrm{~nm}$ 대의 흡광도가 감소 및 시프트 되는 것이 관찰되었고, 발효기간이 길어질수록 아미노산과 관련이 있는 $2,050 \mathrm{~nm}$ 대의 흡광도가 증가하는 것을 관찰 할 수 있었다. 전통 재래식 발효메주를 속부분과 겉부분으로 분리하여 $1,000-2,250 \mathrm{~nm}$ 에서의 가시광 스펙트 럼과 근적외 스펙트럼 데이터로 판별분석한 결과, 겉부분 과 속부분이 잘 판별되었고, 가시광 보다는 근적외 영역에 서 잘 구분되었다. 이들 전통메주중의 아미노산 농도를 비 파괴 측정하기 위해 $\mathrm{PLSR}$ 한 결과 $\mathrm{R}^{2}$ 은 0.9 이상이며, RMSECv $0.23 \%$ 로 나타났으며, 전통메주중의 수분함량도 $\mathrm{R}^{2} 0.81, \mathrm{RMSECv} 0.83 \%$ 이어서 근적외 분광법으로 전통메 주의 품질을 비파괴 측정 가능할 것으로 판단되었다. 


\section{감사의 글}

본 연구는 경북대학교 $\mathrm{KNU}$ 학술연구비의 지원에 의해 수행된 것으로 이에 감사드립니다.

\section{References}

1. Iwamoto M (1983) Prospect and development of food analyzing technique using near infrared spectroscopy. Japan Food Industry, 10, 20-26

2. Kim BS (1994) Quality evaluation of traditional brewed soy sauce and hot bean paste by near infrared reflectance spectroscopy. MS Thesis, Kyungpook National University, Korea, p 3-4, p 24-25

3. Yasuhira H, Yokota Y, Kitamura Y (1989) Application of NIRS analysis in miso. Poster presented at $2^{\text {nd }}$ International NIRS Conference, Tsukuba, Japan

4. Kaneko K, Tachi H, Kikuchi S, Itoh H, Tanaka H (1992) Analysis of soy sauce Ingredient by near infrared spectrophotometry. Japan Shoyu Kenkyu, 18, 60-65

5. Kim SB, Hayase F, Kato H (1985) Decolorization and degradation products of melanoidin on ozonolysis. Agric Biol Chem, 49, 785-792

6. Chung JH, Mok CK, Lim SB, Woo GJ, Baek HH, Park YS (2002) Desalination of traditional soy sauce using electrodialysis. Korean J Food Sci Technol, 34, 811-817

7. Mok CK, Song KT, Lee JY, Park YS, Lim SB (2005) Changes in microorganisms and enzyme activity of low salt soybean paste (Doenjang) during fermentation. Food Engineering Progress, 9, 112-117

8. Park BJ, Jang KS, Kim DH, Yook HS, Byun MW (2002) Changes of microbiological and physicochemical characteristics of Doenjang prepared with low salt content and gamma irradiation. Korean J Food Sci Technol, 34, 79-84

9. Park KY, Lee ES (1989) Effect of ammonia and $\mathrm{pH}$ on the degradation of aflatoxin B1 during the storage of Korean soy sauce (Kanjang). J Korean Soc Food Nutr, $18,115-122$

10. Cho HH, Lee SM, Park SW, Cho RK (2014) Observation for drying non-uniformity of allium vegetables using NIR spectroscopy. Korean J Food Preserv, 21, 838-843

11. Harding V, Warneford FHS (1916) The Ninhydrin reaction with amino-acids and ammonium salts. J Biol Chem, 25, 319-335

12. Song YC, Lee SP (2013) Evaluation in physicochemical properties of soy sauce fortified with soymilk residue (okara koji). Korean J Food Preserv, 20, 818-826

13. Cho RK, Lee KH, Lee JH, Kwon YG (1994) A study for automatic analysis of qualysis of quality components in tabacco leaves using non-destructive analytical method. Agric Chem Biotech, 37, 349-355

14. Bai W, Yoshimura N, Takayanagi M (2014) Quantitative analysis of ingredients of blueberry fruits by near infrared spectroscopy. J Near Infrared Spectrosc, 22, 357-365

15. Saito $K$, Yamagata $T$, Yoshimura $N$, Kanno $M$, Takayanagi M (2016) Discrimination of cellulose fibers by infrared spectroscopy and linear discriminant analysis. Poster presented at $5^{\text {th }}$ Asian Near-infrared Symposium, November 30, Kagosima, Japan

16. Lee JH, Kim MH, Im SS (1991) Antitoxidative materials in domestic Meju and Doenjang 1. Lipid oxidation and browning during fermentation of Meju and Doenjang. J Korean Soc Food Nutr, 20, 148-155

17. Soumya R, Ramaswamy CA John SS, Mark OW, Robert BB (1993) Determination of moisture content of mushrooms by Vis-NIR spectroscopy. J Sci Food Agric, 63, 355-360

18. Matoba $\mathrm{T}$, Kamishikiryo-Yamashita $\mathrm{H}$, Tatara $\mathrm{M}$, Takamura H (1994) Effect of secondary structure of protein on determination of protein content by near infrared spectroscopy. Nippon Shokuhin Kogyo Gakkaishi, 41, 65-69

19. Liu Y, Cho RK, Sakurai K, Miura T, Ozaki Y (1994) Studies on spectra/structure correlations in near-infrared spectra of proteins and polypeptides Part I: A maker band for hydrogen bonds. Applied Spectroscopy, 48, 1249-1254

20. Lee JG, Kwon KI, Choung MG, Kwon OJ, Choi JY, Im MH (2009) Quality analysis on the size and the preparation method of Meju for the preparation of Korean traditional soy sauce (Kanjang). J Appl Biol Chem, 52, 205-211

21. Ahn SC, Bog HJ (2007) Consumption pattern and sensory evaluation of traditional Doenjang and commercial Doenjang. Korean J Food Culture, 22, 633-644

22. Kim ND (2007) Trend of research papers on the soy sauce tastes in Japan. Food Industry and Nutrition, 12, 40-50

23. Kwak EJ, Park WS, Lim SI (2003) Color and quality properties of Doenjang added with citric acid and phytic acid. Korean J Food Sci Technol, 35, 455-460

24. Park JS, Lee MY, Kim JS, Lee TS (1994) Compositions 
of nitrogen compound and amino acid in soybean paste (Doenjang) prepared with different microbial sources. Korean J Food Sci Technol, 26, 609-615

25. Kato H, Cho RK, Okitani A, Hayase F (1987) Responsibility of 3-deoxyglucosone for the glucose induced polymerization of proteins. Agric Biol Chem, 51, 683-689

26. Sohn MR, Cho RK (1994) Polymerizing characters of glycosylated lysozyme monomer. Korean J Food Sci Technol, 3, 256-260

27. Kim JS, Moon GS, Lee YS (2006) Chromaticity and brown pigment patterns of soy sauce and uhyukjang, Korean traditional fermented soy sauce. Korean J Food Cookery Sci, 23, 642-649

28. Iizuka K, Aishima T (1999) Differentiation of soy sauce by pattern recognition analysis of Mid-and Near-IR spectra. J Food Compos Anal, 12, 197-209

29. Ouyang Q, Chen Q, Zhao J, Lin H (2013) Determination of amino acid nitrogen in soy sauce using NIR spectroscopy combined with characteristic variables selection and extreme learning machine. Food Bioprocess Technol, 6, 2486-2493
30. Kobayashi Y, Katayama N (2016) Chemical composition changes in fermentation process of Japanese Miso (Homemade Bean Paste) by NIR Study, Poster presented at $5^{\text {th }}$ Asian Near-infrared Symposium, November 30, Kagosima, Japan

31. Chen JY, Waizumi Y, Wang S, Liu XF, Zang H, Watanabe T, Tamura T, Kyouno N, Miao Y (2016) Correlating visible/near infrared spectra with sensory evaluations values of Miso paste. Poster presented at $5^{\text {th }}$ Asian Near-infrared Symposium, November 30, Kagosima, Japan

32. Suttiwijitpukdee N, Ikehata A (2016) Kinetic analysis of visible-near infrared spectra in maillard reaction. Poster presented at $5^{\text {th }}$ Asian Near-infrared Symposium, November 30, Kagosima, Japan

33. Zang H, Waizumi Y, Wang S, Liu XF, Watanabe T, Tamura T, Kyouno N, Miao Y, Chen JY (2016) Realationship between visible/near infrared spectra and sensory evaluations of soy sauce. Poster presented at $5^{\text {th }}$ Asian Near-infrared Symposium, November 30, Kagosima, Japan 